Article

\title{
Economic Analysis of Diesel-Fuel Replacement by Crude Palm Oil in Indonesian Power Plants
}

\author{
Petr Procházka ${ }^{1}$ and Vladimír Hönig ${ }^{2, *}$ \\ 1 Department of Economics, Faculty of Economics and Management, Czech University of Life Sciences \\ Prague, Kamýcká 129, 16921 Prague 6, Czech Republic; pprochazka@pef.czu.cz \\ 2 Department of Strategy, Faculty of Business Administration, University of Economics, Prague, \\ W. Churchill Sq. 1938/4, 13067 Prague 3, Czech Republic \\ * Correspondence: vladimir.honig@vse.cz; Tel.: +420-224-098-354
}

Received: 19 January 2018; Accepted: 22 February 2018; Published: 27 February 2018

\begin{abstract}
Indonesia needs to find an alternative fuel to substitute diesel in their power plants in order to reduce the use of nonrenewable energy sources. The Indonesian government has a target to reduce oil fuel consumption while improving the efficiency of energy utilization. Crude palm oil is proposed to be used for this substitution. In this paper, the authors conduct an economic analysis of the replacement of diesel by crude palm oil. To predict future prices, a time series analysis is conducted using AutoRegressive Integrated Moving-Average method. A financial analysis of a specific project (0.75-MW power plant) is conducted using static financial indicators (payback period, return on investment). Results show that replacing diesel with crude palm oil may be profitable. This is especially true for the proposed prospects of diesel price evolution. Analysis shows that the price of crude oil, which is the main factor in the pricing of diesel, may go up. Also, recently Indonesian currency depreciated against the US dollar, which also implies a higher cost of diesel.
\end{abstract}

Keywords: biomass; renewable energy; power plant; diesel; crude oil

\section{Introduction}

An increased demand for biofuels can be observed in many countries around the world. Indonesia has become the world's biggest palm oil producer, with more than 20 million tons of crude palm oil (CPO) production, with an annual growth rate of about 10 percent [1]. This fact unfortunately also has led to deforestation and the reduction of biodiversity. While deforestation is bad per se, it is possible to see that this deforestation may be partially offset-from an environmental standpoint-by the replacement of diesel fuel with crude palm oil in Indonesian power plants. According to our analysis, the diesel price seems to be fluctuating more compared to the $\mathrm{CPO}$ price [2,3]. Crude palm oil is a renewable resource. Therefore, using it for electricity generation seems to be a more sustainable solution for Indonesia, compared to the current use of diesel [4,5]. At the same time, it must be mentioned that the change of land use into palm oil plantations is associated with some environmental degradation [6].

Palm oil is also used for electricity generation in Malaysia [7]. According to Perusahaan Listrik Negara (PLN) Electricity Statistics, the industrial sector is the second largest electricity buyer in Indonesia [8]. The government of Indonesia has a target to reduce oil fuel consumption by replacing it with other forms of energy (diversification) and improving the efficiency (conservation) of energy utilization both upstream and downstream. Indonesia aims to reduce oil use by $20 \%$ and increase renewable energy utilization from $17 \%$ to $25 \%$ by 2025 , while also achieving its target of greenhouse gas (GHG) emissions reduction of $26 \%$ by 2020. In 2014, oil power plants represented $23 \%$ of energy 
consumption mix for the industry sector in Indonesia. PLN itself, according to their 2014 statistics, has about $2.6 \mathrm{GW}$ of installed capacity that is powered with diesel plants.

All kinds of liquid fuels occurring in a natural (raw) state are composed of three main components: total water content, ash matter, and combustibles. This composition can be expressed by Formula (1):

$$
\sigma(\mathrm{Wtr})+\sigma(\mathrm{Ctr})+\sigma(\mathrm{Htr})+\sigma(\mathrm{Or})+\sigma(\mathrm{Str})+\sigma(\mathrm{Nr})+\sigma(\mathrm{Atr})=100 \%
$$

where $\sigma(\mathrm{Wtr}), \sigma(\mathrm{Ctr}), \sigma(\mathrm{Htr}), \sigma(\mathrm{Or}), \sigma(\mathrm{Str}), \sigma(\mathrm{Nr})$, and $\sigma(\mathrm{Atr})$ are weight parts of total water, carbon, hydrogen, oxygen, sulphur, nitrogen, and ash amounts in the original sample (\% weight) [9].

Water and ash matter are contained as the non-flammable part of fuel, described as ballast. The flammable part of fuel is composed of carbon, hydrogen, sulphur, and nitrogen. Just carbon, hydrogen, and sulphur are involved in the exothermic reaction with air oxygen-autogenous burning. Oxygen involved in fuel works as an oxidant, and nitrogen is the only part which is not involved in burning [10-14].

All of the main three fuel components (water, ash, and flammables) are very important factors in the combustion process. Their properties greatly influence the construction of combustion equipment as well as its operation regime [15-20]. Figure 1 shows unit process of a palm oil plantation [8].

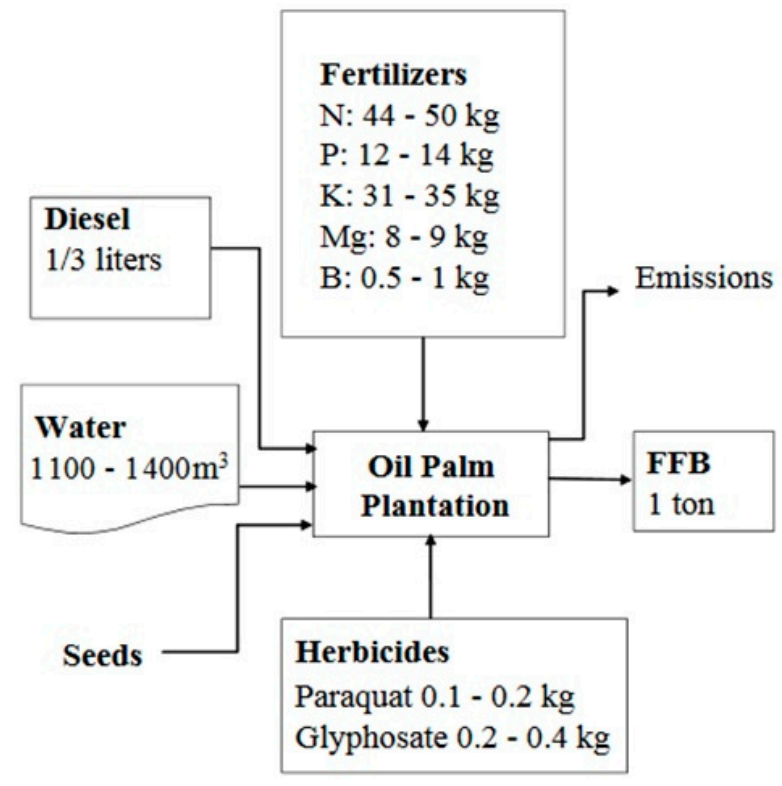

Figure 1. Unit process of a palm oil plantation (FFB-fresh fruit bunch).

The environmental process of palm oil production and processing has been already known for a long time [21].

Perusahaan Listrik Negara (PLN) built a 10-megawatt power plant fueled by crude palm oil (CPO) in Dumai, Riau Province. The power plant was initially fueled with diesel, but was later converted to a crude palm oil (CPO)-fueled power plant by installing converter equipment at the plant [22]. These modifications of existing plants consist, among other factors, of new circulation and processing modules. It is necessary to provide a thorough economic analysis of this investment into a power plant. This is mainly necessary as there are several factors that play a dominant role in the success of a plant, such as subsidies for diesel provided by Indonesian government as well as the price of underlying commodities, specifically West Texas Intermediate (WTI) crude oil [23].

Figure 2 shows the energy efficiency of palm oil as an energy excess of the potential energy of palm oil [20]. 


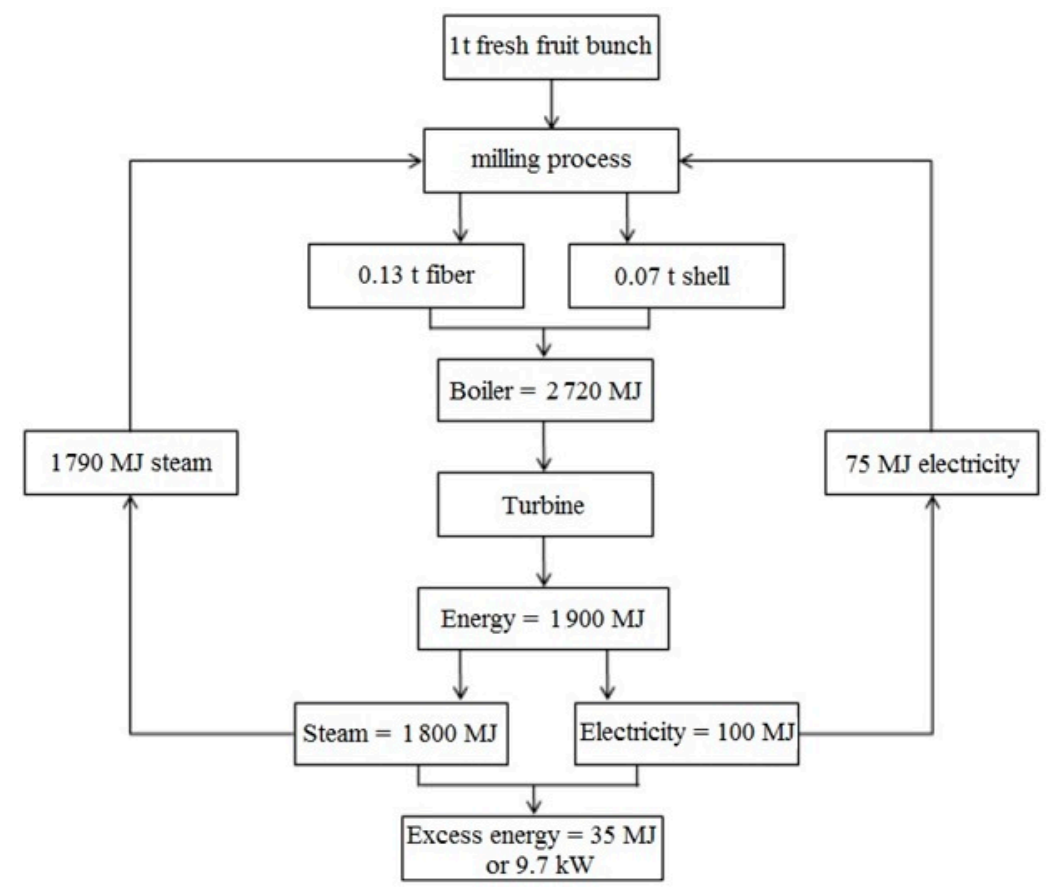

Figure 2. Energy excess of the potential energy of palm oil.

Recently, the price of diesel has grown in Indonesia. The price of subsidized diesel was raised from IDR 6400 (USD \$0.49) to IDR 6900 (USD \$0.53) per liter (+7.8\%) in March 2015 in Indonesia. The current price of palm oil is IDR 10,116 (USD \$0.77) [24]. The price increase was considered necessary as crude oil prices had increased over the past month, while the rupiah continued to depreciate. Since the beginning of 2015, the Indonesian government has drastically reduced public spending on fuel subsidies in a move to free-up funds for structural economic and social development by scrapping a large chunk of fuel subsidies. The system of diesel subsidies can be described by the following, shown in Figure 3 [25].

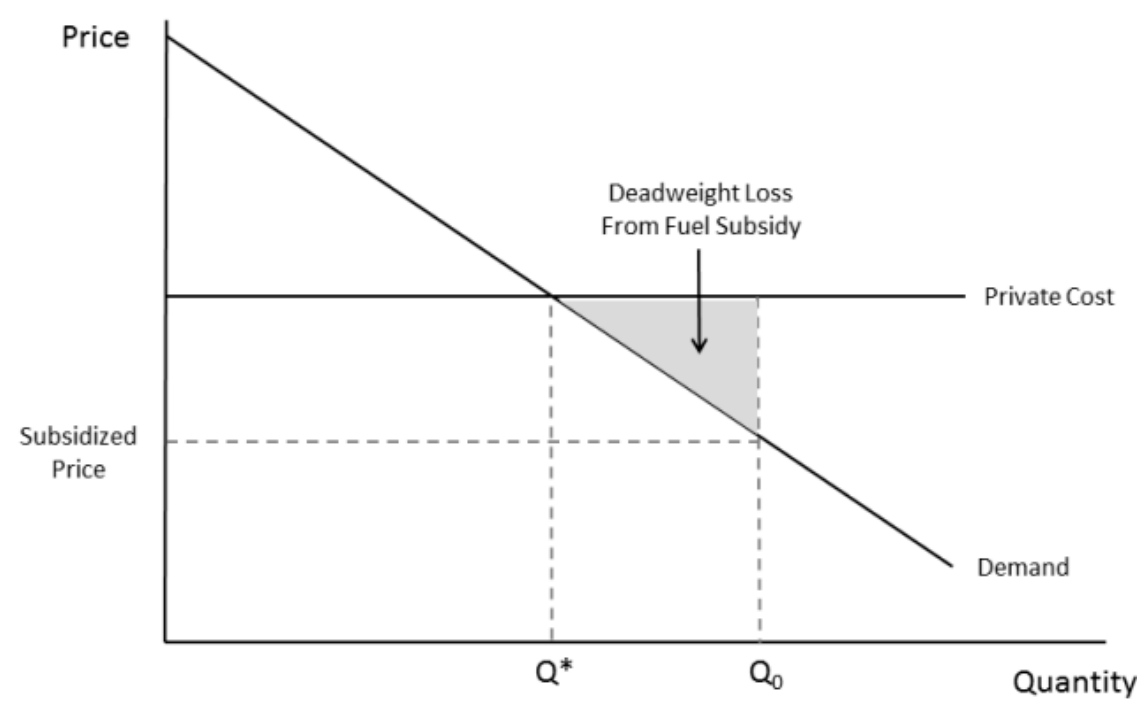

Figure 3. Diesel subsidies in Indonesia.

It is clear from Figure 3 that a system of subsidies always leads to an ineffective economy. The portion depicted by the grey triangle is lost to society as a result of government intervention. 
While $Q^{*}$ signifies an efficient market level, $Q_{0}$ is the level associated with the given Indonesian subsidies. In order to understand a market price of diesel, its structure must be introduced. Generally, the price of diesel can be decomposed into the following parts, as depicted in Figure 4 [26].

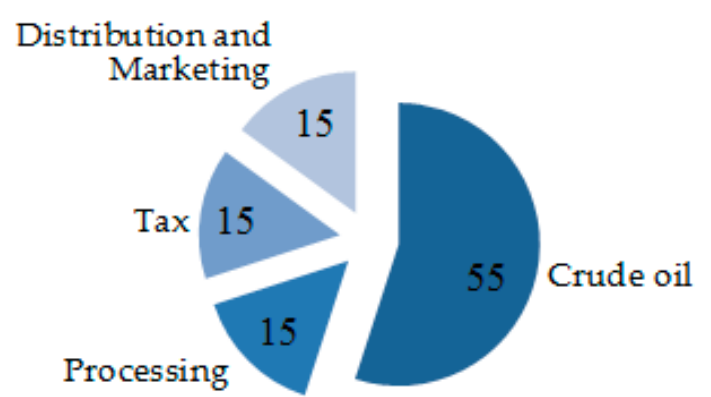

Figure 4. Typical price structure for diesel fuel.

Figure 4 clearly shows that, in general, the price of crude oil has a more than $55 \%$ influence on the final price of diesel. This differs based upon different legal and economic conditions but, generally speaking, roughly one half of the price of diesel depends upon the price of crude oil commodity [27-29]. The crude palm oil price structure is similar to that of diesel fuel. The biggest difference is the application of a lower tax rate for CPO. Necessarily, an economic evaluation of a new power plant depends not only on the current price and exchange rate, but also on future prices and currency value. In the following section, an analysis of WTI crude oil price is conducted using an AutoRegressive Integrated Moving-Average model.

\section{Materials and Methods}

Measurements of $\mathrm{CPO}$ and diesel consumption were conducted in Indonesia using the available technology combined with a scale for weight measurement. Volume was calculated by weight reduction measurement using the relationship among standard density, weight, and volume. This was repeated 10 times. Researchers calculated the arithmetic average of these measurements and estimated the annual consumption. This was done for both diesel and CPO. The power generation of an Indonesian power plant was estimated, assuming that the power plant will not be available $10 \%$ of the time within a year.

ARIMA models provide a unique approach to time series forecasting by describing autocorrelations in the data. In ARIMA models, the variable of interest is forecasted using a linear combination of historical values of the variable. The data for modeling were collected based on historical prices of WTI crude oil. ARIMA stands for AutoRegressive Integrated Moving-Average. The order of an ARIMA model is usually denoted by the notation ARIMA $(p, d, q)$, where $p$ is the order of the autoregressive part (AR), $d$ is the order of the differencing, and $q$ is the order of the moving-average (MA) process. ARIMA model was estimated as ARIMA $(1,1,1)$, as an Augmented Dickey Fuller test proved the existence of a unit root in the time series. ARIMA helps us to understand the data and to predict future data points [30]. The general ARIMA model can be written as Equation (2):

$$
W_{t}=\mu+\frac{\theta(B)}{\phi(B)} \cdot a_{t}
$$

where $t$ is the index of time, $W_{t}$ is the response series $Y_{t}$ or a difference of the response series, $\mu$ is the mean term, operator $a_{t}$ is the independent disturbance, also called the random error, and $B$ is the backshift operator, which is given by Equation (3):

$$
B X_{t}=X_{t-1}
$$


$\varphi(B)$ is the autoregressive operator, represented as a polynomial in the backshift Equation (4):

$$
\phi(B)=1-\phi_{1} B-\ldots-\phi_{p} B^{p}
$$

$\theta(B)$ is the moving-average operator, represented as a polynomial in the backshift Equation (5):

$$
\theta(B)=1-\theta_{1} B-\ldots-\theta_{q} B^{q}
$$

For differencing without seasonality adjustments, we can use Equation (6):

$$
W_{t}=(1-B)^{d} Y_{t}
$$

When appropriate orders are substituted, a model for ARIMA $(1,1,1)$ that is estimated in econometric software GAUSS can be written out as Equation (7):

$$
(1-B) Y_{t}=\mu+\frac{\left(1+\theta_{1} B\right)}{\left(1-\phi_{1} B\right)} \cdot a_{t}
$$

Results of the ARIMA model are tested for white noise, and goodness of fit is tested using Schwarz (also known as Bayesian), Hannah-Quinn, and Akaike information criteria in GAUSS [31]. Also using GAUSS, the existence of an association between the response and each term autoregressive (AR) and moving average (MA) is tested for statistical significance, whereas the $p$-value for the term is compared to a significance level for a given null hypothesis. For the financial analysis, the following formulas are used. In order to calculate how long the investment takes to recoup, the payback period is calculated using Equation (8):

$$
p p=\frac{p-n}{p}+n_{y}=1+n_{y}-\frac{n}{p}
$$

where $p p$ is the payback period, and $n_{y}$ is the number of years after the initial investment at which the last negative value of cumulative cash flow occurs. $n$ is the value of cumulative cash flow at which the last negative value of cumulative cash flow occurs, and $p$ is the value of cash flow at which the first positive value of cumulative cash flow occurs.

Also, return on investment is calculated by Equation (9):

$$
R O I=\frac{P}{C} \cdot 100
$$

where $P$ is the net profit and $C$ is the cost of investment.

For volatility calculation, standard deviation is calculated using Equation (10). The standard deviation is known as $\sigma$ (sigma) and is calculated as follows:

$$
\sigma=\sqrt{\frac{\sum(x-\mu)^{2}}{N}}
$$

where $x$ represents each value in the population, $\mu$ is the mean value of the population, $\Sigma$ is the summation (or total), and $N$ is the number of values in the population.

\section{Results and Discussion}

Figure 5 shows the development of WTI crude oil prices between 2002 and 2017 with a prediction for four consecutive quarters using the identified ARIMA model [32]. The prediction for 2017-2018 does not take into account fundamental analysis factors such as the influence of shale gas, politics of Organization of the Petroleum Exporting Countries (OPEC), etc. 


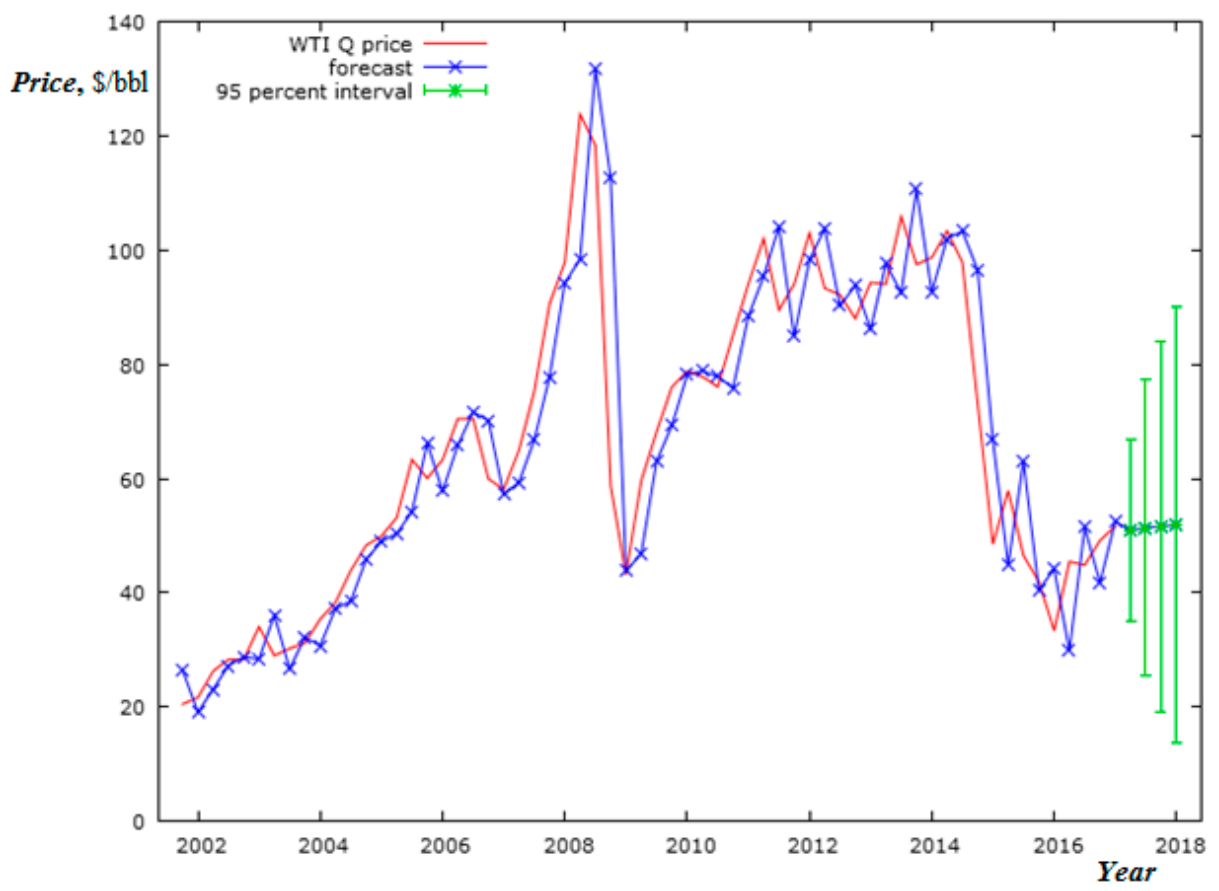

Figure 5. Western Texas Intermediatecrude oil price development and prediction (own compilation).

The prediction for the year 2017-2018 is based upon an ARIMA model that is summarized in Table 1.

Table 1. Model 1: ARIMA, using observations 1986:2-2017:1 ( $\mathrm{T}=124)$ Dependent variable: (1-L) v1-Standard errors based on Hessian.

\begin{tabular}{|c|c|c|c|c|c|c|c|}
\hline & Coefficient & & Std. Error & $\mathbf{Z}$ & $p$-Value & & \\
\hline Const & 0.254807 & & 0.710035 & 0.3589 & 0.71970 & & \\
\hline phi_1 & 0.142828 & & 0.14087 & 1.0139 & 0.31063 & & \\
\hline theta_1 & 0.340985 & & 0.128735 & 2.6487 & 0.00808 & & $* * *$ \\
\hline Mean dependent var & & 0.251909 & & S.D. dependent var & & 6.801058 & \\
\hline Mean of innovations & & 0.000911 & & S.D. of innovations & & 6.086578 & \\
\hline Log-likelihood & & -577.3991 & & Akaike criterion & & 1162.798 & \\
\hline Schwarz criterion & & 1175.548 & & Hannan-Quinn & & 1167.968 & \\
\hline
\end{tabular}

*** Significant on $99 \%$ level.

Table 1 presents a constant (const), a vector of AR coefficients (phi_1), and a vector of MA coefficients (theta_1). Results show that the theta moving-average (MA) operator (theta_1), which is represented as a polynomial in the backshift operator, is significant at the $99 \%$ level. At the same time, the autoregressive coefficients parameter (AR) is insignificant. Therefore, this model was compared to other variations using information criteria to see how well the model fits the data. The estimated criteria (Akaike, Hannah-Quinn, and Schwarz) were used to identify the best ARIMA model. These are also presented in Table 1. Using these criteria, researchers decided to keep the model and conduct a prediction that is found in Figure 5.

The price prediction for 2017-2018 shows a slight increase, with the level reaching almost $\$ 60$ dollars by the last quarter of 2018. The authors acknowledge that the prediction power of this model is limited and other fundamental factors such as the overall supply in the market, etc. must be taken into consideration.

At the same time, as previously mentioned, the exchange rate also influences the domestic prices of diesel. The Indonesian rupiah (IDR) has been depreciating in the last several months. This is obvious from Figure 6, where a (United States dollar) USD/IDR comparison shows the growing depreciation of the Indonesian rupiah against the US dollar from September 2017. It also shows a moving average 
of 30 days $(\mathrm{MA}, 30)$ that can be used for forecasting the future development of this exchange rate. This (MA, 30) gives us a smoothed moving average over the longer time period.

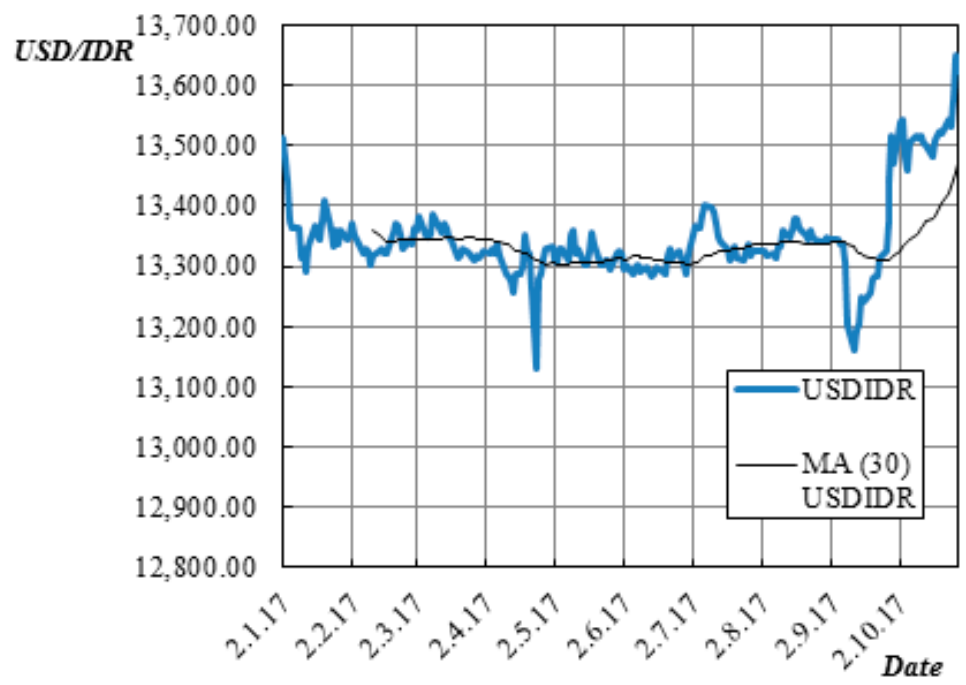

Figure 6. Development of Indonesian rupiah (IDR) vs. United States dollar (USD) rate (1 = January 2017).

Since the start of September 2017, Indonesia's rupiah has tumbled 2.1\% against the US dollar, being one of the worst performing emerging Asian currencies this year [33]. This is also obvious from the moving average indicator in Figure 6.

As the price of oil is an essential factor determining the price of diesel, it is necessary to evaluate the price of $\mathrm{CPO}$ relative to the price of crude oil. This is done in Figure 7. Prices of crude palm oil are based upon a fixed conversion from tons to barrels that takes into account appropriate temperature and density of $\mathrm{CPO}$ [34].

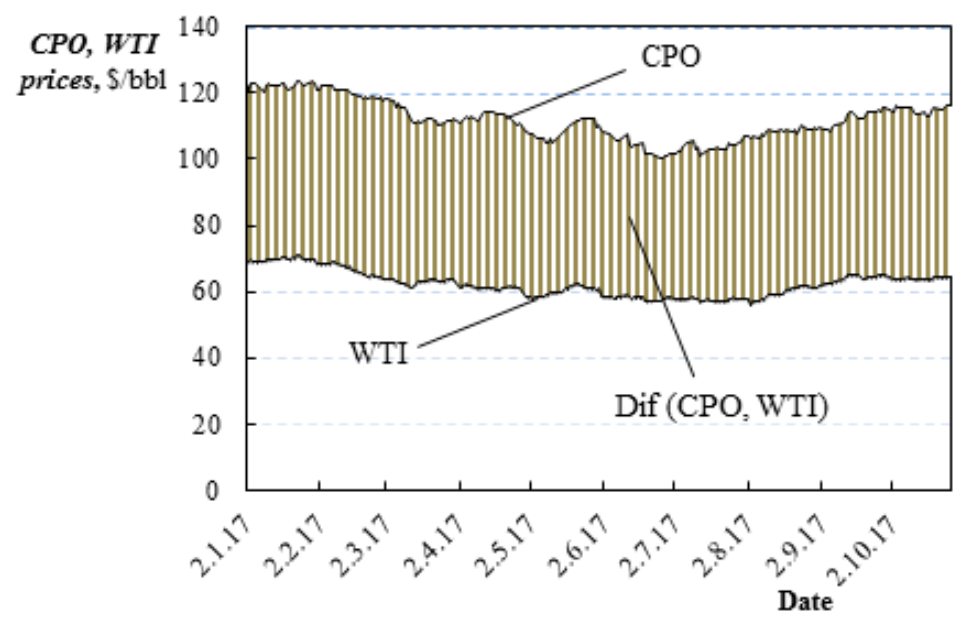

Figure 7. WTI crude oil price (full) vs. price of CPO (dotted) 1 = January 2017. Crude Palm Oil; West Texas Intermediate.

Figure 7 shows difference between WTI and CPO [25,33]. While the WTI crude oil price is currently lower, we do not know which one is relatively more stable. This can also be tested by evaluating the volatility. Historical price volatility is a measure of the magnitude in percentage terms of daily price changes over a specified period of time. The standard deviation is calculated (movement from the average) over the past 30 days of the daily changes in price in percentage terms, and then the percentage is annualized [35-37]. 
This was conducted for both series with the following results that are summarized in Table 2.

Table 2. Standard deviation for WTI crude oil and CPO.

\begin{tabular}{cc}
\hline CPO & WTI \\
\hline 3.81 & 2.84 \\
\hline
\end{tabular}

The results show that the WTI price is less volatile. Now, this analysis can be used to evaluate the economy of crude palm oil power plants in Indonesia. We can also see that both time series seem to be moving closely together, which may be tested through further research.

Given the introduced data, the economy of a 0.75-MW power plant can be analyzed. For the diesel price, the current subsidized price is selected [25,33]. For the CPO price, the current price in the market is chosen. Annual consumptions in liters of diesel or CPO, respectively, were estimated based on experiments conducted in Indonesia that are described in the methods section. Experiments show that, due to its chemical nature, $\mathrm{CPO}$ provides less energy per liter and thus in order to produce the same amount of electricity, a higher volume of fuel is needed. Annual power generation was estimated based on the data of an Indonesian power plant. Researchers assume technological breaks of $10 \%$ within one year. The fixed cost in Table 3 is based on the total cost associated with the conversion that was conducted by an undisclosed technological firm. All data are summarized in Table 3. It must be acknowledged that with a larger output as with, for example, the existing 10-MW power plant, the economies of scale may contribute to even better economic results.

Table 3. Economy of a CPO power plant in Indonesia.

\begin{tabular}{ccc}
\hline & Diesel & Crude Palm Oil \\
\hline Price (USD/1 & 0.99 & 0.86 \\
Annual consumption (l per year) & $1,397,530$ & $1,533,211$ \\
Fixed cost (USD) & 280,000 \\
Total electricity produced (kWh per year) & & $5,913,000.00$ \\
Fuel cost (USD per year) & $1,383,554.7$ & $1,318,561.46$ \\
Fuel cost per 1 kwh (USD/kWh) & 0.23 & 0.22 \\
Fuel cost savings/kWh (USD/kWh) & & 0.01 \\
Annual savings on fuel (USD per year) & & $64,993.24$ \\
Payback period (years) & & 4.3 \\
Return of investment $(\%)$ & 23.21 \\
\hline
\end{tabular}

The Table 3 shows excellent results for the investment with both profitability indicators being extremely high (approximately 4 years payback period and 23.2\% return on investment). The economy of this project looks even better while prospects for diesel prices are relatively dim in Indonesia due to the cutting of government spending on diesel subsidies.

Results may be altered in light of the predicted increase in prices from ARIMA forecasting (Figure 5).

Market participants use volatility values to gauge uncertainty in factors that have influence on oil markets, including supply, demand, and geopolitical or macroeconomic events [38]. This has been conducted for both series with the following results that are summarized in Table 2.

At the same time, economic performance over the past decade as characterized by an average real GDP growth of 5.2\% increased the demand for electricity [1]. Due to increased demand and insufficient supply, state-utility PT. Perusahaan Listrik Negara (PLN) has been forced to implement frequent rolling blackouts in Java and Bali [22]. Also, according to PLN, about one third of Indonesia's population still does not have access to electricity [1]. The national electricity demand is expected to grow, on average, at around $8.5 \%$ per year over the period from 2015 to 2021, indicating an electricity demand at around 358 TWh in 2019 [39]. 
Diesel power plants have the highest generating cost per kWh compared to other types of power plants in Indonesia [40-43]. So, renewable energy power plants make a viable business for both PLN and the private sector [1,35]. The investment needed to convert a 10-MW diesel-fueled power plant into a 10-MW CPO-fueled power plant is anywhere between IDR 22 billion (US \$1.9 million) and IDR 29 billion. The investment figure is dependent on how many engines a power plant has and the size of the engines. Replacing diesel with CPO to fuel a power plant could eventually reduce production costs by between $40 \%$ and $60 \%$, according to Indonesia-Investments [25]. Based on the current price of oil, the conversion of a 15-MW diesel-fueled power plant will save up to $\$ 4.5$ million per year in electricity production costs $[25,44]$.

It can be argued that implementation of more renewable energy may be, for example, insufficient grid infrastructure [40]. At the same time, using renewable energy sources may contribute to higher energy security [41].

It is necessary to ensure the supply of resources for energy production in timely manner. This will mean that more plants that would use renewable resources can be employed. It is also possible that the government may provide certain incentives for potential investors that would invest into this conversion. These could include various tax benefits or subsidies [45-48].

Transport fuels are highly subsidized in Indonesia, resulting in fuel prices that are among the lowest in Asia [42]. Currently, about $43 \%$ of the actual costs of diesel are covered by the government through subsidies [49]. The Indonesian government will consider letting the price of subsidized fuel float by keeping the subsidy at a fixed amount. The Indonesian administration will suggest a permanent fixed subsidy rate, which might be 1000 or 2000 rupiah per liter, and the vice-president expressed confidence that the new policy could be implemented next year, according to a recent report [50].

\section{Conclusions}

In this paper, it was that the use of CPO instead of diesel can be highly prospective in Indonesia since CPO prices are low and diesel subsidies provided by the government have been decreasing. Analyzed power plant conversion yields approximately 23.2\% return on investment and a payback period of roughly 4 years. Indonesia has a chance to become one of the world's leaders in green electricity production since $\mathrm{CPO}$ is a renewable resource. The main obstacle to the proposed project may be the high initial investment. However, foreign investors can potentially be involved in these projects. It can be also recommended to go ahead with the project of diesel replacement, as the predicted price of oil based on the estimated time series model seems to be going up. This may, as already mentioned, lead to increases in the price of diesel in Indonesia. Other factors that influence the economy of diesel replacement are also favorable for the project. For example, Indonesian currency has been depreciating, thus contributing to the higher price of diesel. Volatility estimates that are calculated in this paper, on the other hand, support the use of diesel, as crude oil, which is the main price determinant of diesel, is less volatile than crude palm oil.

Acknowledgments: The paper was created with the grant support project IGA University of Economics, Prague F3/19/2016-Economic efficiency of biofuels from waste materials.

Author Contributions: Petr Procházka and Vladimír Hönig conceived and designed the experiments; Petr Procházka and Vladimír Hönig performed the experiment and analyzed the data; Petr Procházka and Vladimír Hönig wrote the paper.

Conflicts of Interest: The authors declare no conflict of interest.

\section{References}

1. McKinsey \& Company. The Archipelago Economy: Unleashing Indonesia's Potential. Available online: http:/ / www.mckinsey.com/insights/asia-pacific/the_archipelago_economy (accessed on 2 September 2017).

2. Azad, A.K.; Rasul, M.G.; Khan, M.M.K.; Sharma, S.C.; Hazrat, M.A. Prospect of biofuels as an alternative transport fuel in Australia. Renew. Sustain. Energy Rev. 2015, 43, 331-351. [CrossRef] 
3. Azad, A.K.; Rasul, M.G.; Khan, M.M.K.; Omri, A.; Bhuiya, M.M.K.; Hazrat, M.A. Modelling of renewable energy economy in Australia. Energy Procedia 2014, 61, 1902-1906. [CrossRef]

4. Gresshoff, P.M.; Hayashi, S.; Biswas, B.; Mirzaei, S.; Indrasumunar, A.; Reid, D.; Samuel, S.; Tollenaere, A.; van Hameren, B.; Hastwell, A. The value of biodiversity in legume symbiotic nitrogen fixation and nodulation for biofuel and food production. J. Plant Physiol. 2015, 172, 128-136. [CrossRef] [PubMed]

5. Bhuiya, M.M.K.; Rasul, M.G.; Khan, M.M.K.; Ashwath, N.; Azad, A.K.; Mofijur, M. Optimisation of Oil Extraction Process from Australian Native Beauty Leaf Seed (Calophyllum inophyllum). Energy Procedia 2015, 75, 56-61. [CrossRef]

6. Murphy, F.; McDonnell, K. Investigation of the potential impact of the Paris Agreement on national mitigation policies and the risk of carbon leakage: An analysis of the Irish bioenergy industry. Energy Policy 2017, 104, 80-88. [CrossRef]

7. Begum, S.; Kumaran, P.; Jayakumar, M. Use of oil palm waste as a renewable energy source and its impact on reduction of air pollution in context of Malaysia. IOP Conf. Ser. Earth Environ. Sci. 2013, 16, 012026. [CrossRef]

8. Pleanjai, S.; Gheewala, S.H.; Garivait, S. Environmental Evaluation of Biodiesel Production from Palm Oil in a Life Cycle Perspective. Asian J. Energy Environ. 2007, 8, 15-32.

9. Bradna, J.; Malat'ák, J. By-products from methyl ester oil production and their thermal-emission properties. Res. Agric. Eng. 2008, 54, 9-21. [CrossRef]

10. Song, Y.; Penmatsa, V.; Wang, C.L. Modeling and Simulation of Enzymatic Biofuel Cells with Three-Dimensional Microelectrodes. Energies 2014, 7, 4694-4709. [CrossRef]

11. Liu, X.; He, H.; Wang, Y.; Zhu, S.; Piao, X. Transesterification of soybean oil to biodiesel using CaO as a solid base catalyst. Fuel 2008, 87, 216-221. [CrossRef]

12. Agarwal, D.; Agarwal, A.K. Performance and emissions characteristics of Jatropha oil (preheated and blends) in a direct injection compression ignition engine. Appl. Therm. Eng. 2007, 27, 2314-2323. [CrossRef]

13. Dorado, M.P.; Ballesteros, E.; Arnal, J.M.; Gómez, J.; López, F.J. Exhaust emissions from a Diesel engine fueled with transesterified waste olive oil. Fuel 2003, 82, 1311-1315. [CrossRef]

14. Demirbas, A. Importance of biodiesel as transportation fuel. Energy Policy 2007, 35, 4661-4670. [CrossRef]

15. Hönig, V.; Hromádko, J. Possibilities of using vegetable oil to power diesel engines as well as their impact on engine oil. Agron. Res. 2014, 12, 323-332.

16. EN 590+A1. Automotive Fuels-Diesel-Requirements and Test Methods; Czech Office for Standards, Metorology and Testing; Deutsches Institut fur Normung E.V. (DIN): Berlin, Germany, 2014; p. 16.

17. Canakci, M.; Van Gerpen, J. Biodiesel production from oils and fats with high free fatty acids. Trans. Am. Soc. Agric. Eng. 2001, 44, 1429-1436. [CrossRef]

18. Ramírez-Verduzco, L.F.; Rodríguez-Rodríguez, J.E.; del Jaramillo-Jacob, A.R. Predicting cetane number, kinematic viscosity, density and higher heating value of biodiesel from its fatty acid methyl ester composition. Fuel 2012, 91, 102-111. [CrossRef]

19. Barnwal, B.K.; Sharma, M.P. Prospects of biodiesel production from vegetable oils in India. Renew. Sustain. Energy Rev. 2005, 9, 363-378. [CrossRef]

20. Nasution, M.A.; Herawan, T.; Rivani, M. Analysis of Palm Biomass as Electricity from Palm Oil Mills in North Sumatera. Energy Procedia 2014, 47, 166-172. [CrossRef]

21. Ng, Y.G.; Shamsul Bahri, M.T.; Irwan Sayah, M.Y.; Mori, I.; Hasim, Z. Ergonomics Observation: Harvesting Tasks at Oil Palm Plantation. J. Occup. Health 2013, 55, 405-414. [CrossRef] [PubMed]

22. The Jakarta Post, PLN Operates First Power Plant Fired by Crude Palm Oil. Available online: http:/ / www.thejakartapost.com/news/2008/10/30/pln-operates-first-power-plant-fired-crude-palmoil.html\#sthash.fMP8j0Up.dpuf (accessed on 7 September 2017).

23. Machek, O.; Hnilica, J. Evaluating the Impact of Family Presence in Ownership and Management on Financial Performance of Firms using Mathed-Pair Investigation. Politicka Ekonomie 2015, 63, 347-362. [CrossRef]

24. GlobalPetrolPrices.com. Available online: http://www.globalpetrolprices.com/Indonesia/diesel_prices/ (accessed on 20 February 2018).

25. Indonesia-Investments. Subsidized Fuel Prices Indonesia Raised due to Oil Price \& Rupiah. Available online: http:/ / www.indonesia-investments.com/news / todays-headlines/subsidized-fuel-prices-indonesiaraised-due-to-oil-price-rupiah/item5429 (accessed on 2 April 2017). 
26. Parry, I.W.H.; Walls, M.; Harrington, W. Automobile Externalities And Policies. J. Econ. Lit. 2007, 45, 373-399. [CrossRef]

27. Knothe, G. Biodiesel derived from a model oil enriched in palmitoleic acid, macadamia nut oil. Energy Fuels 2010, 24, 2098-2103. [CrossRef]

28. Azad, A.K. Biodiesel from Mandarin Seed Oil: A Surprising Source of Alternative Fuel 2017. Energies 2017, 10, 1689. [CrossRef]

29. Rasid, N.S.A.; Syed-Hassan, S.S.A.; Kadir, S.A.S.A.; Asadullah, M. Life Cycle Assessment to Evaluate the Green House Gas Emission from Oil Palm Bio-Oil Based Power Plant. Korean J. Chem. Eng. 2013, 30, 1277-1283. [CrossRef]

30. Tsay, R.S. Analysis of Financial Time Series, 3rd ed.; John Wiley \& Sons, Inc.: Hoboken, NJ, USA, $2010 ;$ p. 712. ISBN 9780470414354. [CrossRef]

31. Aptech Systems, Inc. Available online: https://store.aptech.com/gauss-platform-category.html (accessed on 5 October 2017).

32. Fred Economic Data, Economic Research. Available online: https://fred.stlouisfed.org (accessed on 5 September 2017).

33. KURZYCZ. Available online: http://www.kurzy.cz/kurzy-men/nejlepsi-kurzy/IDR-indoneska-rupie/ (accessed on 7 September 2017).

34. Aussie Mandarins. Available online: http:/ / www.aussiemandarins.com.au/industry (accessed on 16 April 2016).

35. Machek, O.; Hnilica, J. Copreneurship and its Impact on Financial Characteristics of Companies. Ekonomicky Casopis 2015, 63, 152-166.

36. Bhuiya, M.M.K.; Rasul, M.G.; Khan, M.M.K.; Ashwath, N.; Azad, A.K. Prospects of 2nd generation biodiesel as a sustainable fuel-Part: 1 Selection of feedstocks, oil extraction techniques and conversion technologies. Renew. Sustain. Energy Rev. 2016, 55, 1109-1128. [CrossRef]

37. Demirbas, A. Biodiesel production from vegetable oils via catalytic and non-catalytic supercritical methanol transesterification methods. Prog. Energy Combust. Sci. 2005, 31, 466-487. [CrossRef]

38. Schwartz, R.; Byrne, J.; Colaninno, A. Volatility Risk and Uncertainty in Financial Markets; Springer: New York, NY, USA, 2011; p. 137, ISBN 978-1-4419-1474-3.

39. Syafii, R.N. Analisis Kontingensi Sistem Tenaga Listrik dengan Metode Bounding. Jurnal Rekayasa Elektrika 2012, 10, 92-97. Available online: http:/ /www.jurnal.unsyiah.ac.id/JRE/article/view/139/132 (accessed on 7 July 2017). [CrossRef]

40. Wang, R.; Sun, L.; Xie, X.; Ma, L.; Liu, Z.; Liu, X.; Ji, N.; Xie, G. Biodiesel production from Stauntonia chinensis seed oil (waste from food processing): Heterogeneous catalysis by modified calcite, biodiesel purification, and fuel properties. Ind. Crops Prod. 2014, 62, 8-13. [CrossRef]

41. Asianpower. Available online: http://asian-power.com/power-utility/commentary/how-strong-regulatorypush-can-jumpstart-indonesias-biomass-sector\#sthash.98Yiabl8.dpuf (accessed on 19 April 2017).

42. Aghamohammadi, N.; Reginald, S.S.; Shamiri, A.; Zinatizadeh, A.A.; Wong, L.P.; Sulaiman, N.M.B.N. An Investigation of Sustainable Power Generation from Oil Palm Biomass: A Case Study in Sarawak. Sustainabillity 2016, 8, 416. [CrossRef]

43. Bazmi, A.A.; Zahedi, G.; Hashim, H. Progress and challenges in utilization of palm oil biomass as fuel for decentralized electricity generation. Renew. Sustain. Energy Rev. 2011, 15, 574-583. [CrossRef]

44. Gillespie, P. Participation and Power in Indonesian Oil Palm Plantations. Asia Pac. Viewp. 2012, 53, $254-271$. [CrossRef]

45. Smutka, L.; Hinke, J.; Pulkrabek, J. Characteristics of Sugar Production in Asian Region. Listy Cukrovarnicke a Reparske 2017, 133, 360-365.

46. Benesova, I.; Maitah, M.; Smutka, L.; Tomsik, K.; Ishchukova, N. Perspectives of the Russian agricultural exports in terms of comparative advantage. Aric. Econ. 2017, 63, 318-330. [CrossRef]

47. Milanovic, V.; Smutka, L. South Asian Countries in the Global Sugar Market: A Critical Assessment. Sugar Tech. 2016, 18, 647-658. [CrossRef]

48. Deutsche Gesellschaft für Internationale Zusammenarbeit (GIZ) GmbH. Available online: http:/ / www.giz. de/expertise/html/4282.html (accessed on 5 September 2017). 
49. Warr, P. The Transmission of Import Prices to Domestic Prices: An Application to Indonesia. Appl. Econ. Lett. 2008, 15, 499-503. [CrossRef]

50. Rieka, R.; Agus, S.; Hendaru, P. Bank Indonesia Raises Key Rate after Fuel-Price Increase. Available online: http:/ / www.bloomberg.com/news/articles/2014-11-17/indonesia-s-widodo-increases-subsidized-gasolinediesel-prices (accessed on 2 April 2017). 